\title{
Tempos de exclusão, eliminação e destruição'
}

\author{
Jorge Olímpio Bento
}

https://doi.org/10.5628/rpcd.08.03.441
Universidade do Porto

Faculdade de Desporto

Portugal

\section{RESUMO}

O mundo está sendo estruturado por uma minoria, sem quaisquer escrúpulos no tocante ao destino que reserva para as outras pessoas: a inevitabilidade da exclusão. É isto que é encenado, de modo exemplar, pelos diversos tipos de reality shows que as cadeias de televisão divulgaram em toda a parte. Não espanta que a maioria dos indivíduos se sinta ameaçada por medos que tornam a vida uma dura e amarga luta para não ser descartado para o caixote do lixo.

Este ambiente é alimentado pela modelação da sociedade segundo os ditames do consumo. Ademais tem reflexos no vocabulário 'reformista', que entrou na Universidade pela mão do 'Processo de Bolonha'; e está associado à transformação da educação superior numa área de negócio, muitas vezes desonesto.

Tudo junto contribui para a degradação da democracia e da liberdade e mostra a banalidade e racionalidade do mal contemporâneo e dos seus agentes. O regresso ao obscurantismo é evidente.

É contra isto que a educação e a formação, os professores e intelectuais humanistas se devem levantar, sabendo que a tarefa é ingente, todavia sem alternativa.

Palavras-chave: medos, exclusão, sociedade de consumo, vocabulário 'reformista', racionalidade do mal contemporâneo, obscurantismo

\section{ABSTRACT \\ Times of exclusion, elimination and destruction 2}

The world is being structured by a minority without any scruples regarding the destiny that awaits for other persons: the inevitability of exclusion. This is what it's staged, so exemplary, by the several types of reality shows that television networks spread everywhere. It is not surprising that most individuals feel threatened by fears that make life a hard and a bitter struggle not to be discarded to the dustbin.

This environment is fed by the moulding of society according to the dictates of consumption. Moreover, it has reflexes in the "reformist" vocabulary, which entered the University by the hand of the 'Bologna Process', and is associated to the transformation of higher education in an area of business, often dishonest.

All of this together contributes to the degradation of democracy and freedom and shows the banality and rationality of the contemporary evil and its agents. The return to the obscurantism is obvious.

It is against this that education and training, teachers and humanist intellectuals should raise, knowing that the task is enormous, however without alternative.

Key-words: fears, exclusion, society of consumption, "reformist" vocabulary, rationality of the contemporary evil, obscurantism 
Se podes olhar, vê. Se podes ver, repara.

(Livro dos Conselhos, In: Ensaio Sobre a Cegueira, José Saramago)

\section{INTRODUÇÃO: CONTEXTO DE MEDOS E INCERTEZAS}

Esta era de vida e sociedade 'líquidas', de consumo e consumidores, de avanço do precário e efémero, do fútil e falso, de descarte e reciclagem ocasiona, entre outras coisas, uma fartura em sentimentos e condições de impotência e incerteza constantes, em paralelo com uma não menor percepção de carência em matéria de segurança e protecção. Regista-se nela uma produção em grande escala de indivíduos amedrontados e sitiados por um massivo regresso de temores e medos, com reacções em tudo semelhantes às dos animais face a presenças que ponham em risco as suas vidas. Mais, os receios têm o dom da ubiquidade: a vida inteira está cheia deles e tornouse uma longa e dura luta para os enfrentar em todo o tempo e lugar.

Desconfiamos de tudo, melhor dizendo, as confianças são assaz débeis e transitórias e não ostentam qualquer garantia que as abalize. Por isso sabemonos e sentimo-nos assustados e expostos a perigos do mais diverso teor, que hão-de vir e abater-se sobre as nossas cabeças como uma pesada, inclemente e cortante espada de Damocles: perigos nos domínios financeiro, climático, ecológico, nuclear, social e profissional, mais os da ordem da saúde, da família, da previdência etc.

As instituições, portadoras e garantes do sentido e dos significados dos direitos da cidadania republicana, são progressivamente esvaziadas e desmanteladas. Entronizado o supremo deus do desregulado mercado neoliberal e da globalização de feição meramente economicista, expropriado o Estado, derrubados o ideal e o modelo governamental do bem-estar social, perdido o controle sobre o mundo natural e outros mundos, as certezas da modernidade exilaram-se, deixando as pessoas abandonadas a uma ansiedade incessante e à imparável influência do medo. É também este que convida ao enclausuramento em shopping centers, nos condomínios fechados e nos automóveis blindados e com vidros fumados. O absurdo e o incompreensível, o imprevisível e o inevitável viraram uma rotina. Aumentam as polari- dades e o fosso entre os que têm muito e os que pouco ou nada têm. Progridem vertiginosamente a separação e a exclusão. Avança assustadoramente a ruptura na comunicação e convivência entre as elites e o resto da população. E assim resvalamos para a descivilização, para a guerra de todos contra todos, para o combate de vida ou morte. Como que a dar razão à gélida e crua apreciação de Konrad Adenauer (1876-1967): "A História é a soma das coisas que poderiam ter sido evitadas".

(À margem desta introdução permito-me agregar um pedido: em regra, as notas de rodapé não merecem muita atenção; rogo ao leitor que, no caso presente, contrarie esse procedimento habitual).

\section{REALITY SHOWS: A INEVITABILIDADE DA EXCLUSÃO}

Os reality shows, que as cadeias televisivas divulgaram a todo o mundo, são uma metáfora da realidade: a inevitabilidade da exclusão. ${ }^{3}$ Esta não é uma possibilidade, mas antes uma certeza cuja confirmação é só uma questão de dias ou semanas e de saber quem será primeiro excluído. Não há forma de escapar e evitar a eliminação, de ser poupado à norma universal do descarte e rejeição. Não há regras nem receitas e também não é necessário fazer nada para merecer a condenação. É um destino inexorável como o da morte, que só podemos tentar manter à distância por algum tempo.

É assim que o mundo está hoje a ser estruturado: não para incluir e posicionar a maioria das pessoas dentro do sistema de realização e afirmação, mas para as atirar para fora, para o caixote do lixo e para o mais longe possível, criando ainda barreiras para se assegurar que elas não voltarão. O formato é ditado por uma minoria, já que, contrariando o que é propalado, a desigualdade de oportunidades é a carta marcada do aviltante e revoltante jogo de identidades contemporâneas. A sorte, a felicidade, a realização luzidia, a exaltação e a ostensiva riqueza de alguns são garantidas pela desdita, pela infelicidade, pela degradante humilhação, pela vergonhosa pobreza e pelo amargo barrar do caminho de muitos. E no tocante à liberdade o panorama é em tudo idêntico: ela conserva e acentua as marcas de uma mercadoria sempre escassa e distribuída de forma desigual, avidamente monopolizada. 
Eis mais uma prova insofismável de que o modelo actual da sociedade da globalização, do mercado e consumo, ao contrário do que tanto propala, não só não é aberto a todos, nem de jure nem muito menos de facto, como resiste fortemente à sua extensão e alargamento. É expressão do insaciável e omnívoro apetite de uns quantos empoleirados nas alturas da riqueza e superioridade e do seu desdém e alheamento face à imensa legião de espoliados que não cessa de engrossar. ${ }^{4}$ Uns poucos gozam de licença de exploração e saque dos muitos surpreendidos e atordoados que persistem em acreditar que a crise é uma inevitabilidade passageira que, para seu futuro bem, devem suportar no presente. Esta sociedade, ao fazer tais concessões aos primeiros e mentir descaradamente aos últimos, coloca-se à margem da cultura, da decência e da moralidade. Não adianta prometer ou querer ver o que não virá: a luz não brilha no fundo do túnel e não vai acender-se a pedido da premência dos desejos e necessidades. O apagão ético e estético está para durar, enquanto se mantiverem a cegueira e o desconcerto das vontades. ${ }^{5}$

"Feridos pela experiência do abandono, homens e mulheres desta nossa época suspeitam ser peões no jogo de alguém, desprotegidos dos movimentos feitos pelos grandes jogadores e facilmente renegados e deitados à pilha do lixo (...) Consciente ou subconscientemente (...) são assombrados pelo espectro $d a$ exclusão" - acusa Zygmunt Bauman. ${ }^{6}$

É este fado trágico que aqueles programas, nomeadamente o célebre Big Brother, trazem à cena.

Mostram-nos, de maneira iniludível, o jogo abjecto que jogamos no dia-a-dia e em todos os palcos da vida. E certificam que a 'arte' ou competência hoje mais apreciada é a da habilidade e 'coragem' - obrigatórias, ensinadas, estimuladas, treinadas e inclusive acordadas e legisladas até à náusea - para agir em conformidade e, antes de ser expulso, botar fora os outros, não por uma razão de indignidade ou demérito da parte deles, mas por imposição de cotas de eliminação que devem ser cumpridas e tocam a todos na sua vez. Não se trata, pois, de reconhecer a valia de uns e punir os erros de outros. Só nos é dada a escolha de apontar aquele que é eliminado num momento e não a de não expulsar ninguém. $\mathrm{E}$ mesmo que tenhamos aversão em participar no jogo da exclusão, isso não nos põe a salvo do facto dos outros nos sancionarem com uma bola preta ou outro símbolo de rejeição, sem dó nem piedade. Somos intimados, por uma espécie de convite irrecusável, a aderir à luta desesperada e desumana da sobrevivência, a dar livre curso aos instintos primários de defesa e conservação. A tornarmo-nos praticantes e apreciadores entusiastas e alienados da obscenidade ou, pelo contrário, a ficarmos estupefactos, tolhidos e reféns da ansiedade e perplexidade perante os abismos ocultos nos calabouços da alma e do ser humano, a sujidade da linguagem e a bestialidade e incredulidade dos actos e gestos tornados habituais e 'normais'. ${ }^{7}$

A função de tais programas, como se fossem os 'contos morais' adaptados à conjuntura, é a de revelar e tornar coisa natural e regular a realidade incontornável da nossa época. Mostram e comprovam, de modo evidente, enfático e eloquente, que o virtual já se transformou em real; habituam-nos e familiarizamnos com a inevitável condenação e eliminação, com o espectáculo rotineiro - diligente e superiormente representado e, portanto, gerador de satisfação - da humilhação, da perdição e imolação de seres humanos, obviamente dos que são mais fracos. Ensinamnos que a ameaça veio para ficar e que não há maneira de conseguir que o desfecho fatal seja evitado, mesmo sem termos feito nada de errado que o possa 'justificar'. 8

O problema reside precisamente aí: não é preciso fazer nada de errado, imprudente e reprovável para ser eliminado; isto impõe-se por si próprio, sem necessidade de motivo aparente e explicação convincente. $\mathrm{O}$ que nos acontece nada ou muito pouco tem a ver com o teor do que fazemos; a linha de fronteira entre virtude e pecado, recompensa e punição é muito ténue. A eliminação (que é a regra universal) e a vitória (que é a excepção) são fortuitas e ficam por conta do acaso. Consequentemente a iminência da exclusão impiedosa e cruel traz consigo a sensação de impotência e um carrossel de medos inevitáveis e irremediáveis. É certo que podem ser iludidos, suspensos e aguentados por algum tempo, mas não destruídos e erradicados em definitivo. Ora isto leva a um jogo de simulações, do faz de conta, do gato e do rato, que será fatalmente perdido ao primeiro descuido. 


\section{CONSUMIDORES E OBJECTOS DE CONSUMO}

Para este ambiente concorrem, em sintonia e a preceito, a modelação e o funcionamento da sociedade segundo a sua caracterização como instância de consumo e consumidores. A vida e a sociedade 'líquidas' ostentam a marca do incentivado consumo. Todos os seus elementos, sejam eles animados ou inanimados, são objectos de consumo. Logo os seres humanos também o são, apenas têm valor e utilidade enquanto conservarem as características, a imagem, a forma e as performances adequadas ao consumo, enquanto despertarem interesse e aceitação, atracção e sedução, enquanto passarem no apertado crivo das avaliações. Tornam-se desqualificados, usados, gastos, desvalorizados, ultrapassados e acabados e são carimbados de 'inadaptados', sem préstimo algum, absolutamente inúteis, impróprios e mesmo nocivos, à medida que vão perdendo capacidade para se encaixarem no quadro de exigências e especificidades do mercado. Não se livram desta punição, se não conseguirem ser jovens vitalícios, iludir, contrariar e atrasar a obsolescência, esconder os traços, sinais e rugas do tempo, renegar a idade e a maturidade a ela inerente, conservar o corpo fiável, apresentar a aparência como essência e ter sucesso no confronto com o vasto e constantemente alterado leque de critérios de validade estabelecidos no fluido código do consumo. 9

Portanto é deveras angustiante e tirânica a obsessão de tentar escapar ao contentor do lixo. Para a acalmar, iludir, sossegar ou adormecer as pessoas submetem-se a cursos, cursinhos e 'acções de formação' acerca de tudo e de nada (como os ilusórios e demagógicos 'cursos de novas oportunidades'), assim como a dietas e privações, a cirurgias plásticas e estéticas e às mais diversas operações de cosmética, de reparação, correcção e reciclagem tanto nos aspectos físico e biológico como nos planos sentimental, comportamental, espiritual e moral.10 Coleccionam diplomas por grosso e atacado, para somar pontos, ambições e ilusões no sistema de avaliação e progressão na carreira e na vida. Sabem que, no dia em que forem reprovados no exame do consumo e cobiça, ficarão sem o cartão de permanência e circulação na avenida existencial, serão riscados e abatidos no inventário dos activos válidos, irremediavelmente removidos da esfera social e profissio- nal, atirados para a infecta lixeira da inaptidão e desqualificação, da desconsideração e rejeição. ${ }^{11}$ Esta ameaça é terrível e não há maneira de se subtrair a ela, porque na sociedade de consumidores ninguém fica de fora do catálogo de objectos de consumo. Toda a gente se move diária e continuamente entre os dois pólos e papéis: ser, em simultâneo, consumidor e objecto de consumo. A distinção entre ambos é à condição (obviamente só para alguns!) e a reversão uma certeza; nenhum é mais poderoso do que o outro.

Por isso mesmo a mais cruel e inumana consequência da sociedade de consumo, com as suas regras, prescrições, imposições e tentáculos estendidos a todos os sectores (notadamente o universitário), é a perspectiva de viver para acabar no monturo do lixo. É este desígnio que acarreta a preocupação mais opressora e que requer e consome o maior dispêndio de atenção, energia e trabalho. A vida gasta-se oscilando entre o prazer do consumo e o prenúncio do horror de ser consumido. As posições não são fixas ou adquiridas para sempre. $\mathrm{O}$ apelo à individualidade e singularidade esbarra na exigência de conformidade às rotinas, ofertas e padrões impostos pelo evangelho do consumo.

Para não soçobrar nessa luta é necessário assumir a mudança não como um direito ou possibilidade, mas como uma ordem, obrigação e obsessão; ou seja, é obrigatório demonstrar a capacidade de mudar, de largar e apagar o ontem, de viver sempre no hoje e não traçar planos para o futuro, de despir o manto a qualquer momento, de ser eternamente indefinido, incompleto, impermanente e inautêntico. Tem que se cultivar o desapego e estar apto a trocar constantemente de objectos, hábitos e comportamentos, a competir pela novidade e a livrar-se de coisas ontem imprescindíveis e beneficiadoras da imagem e da identidade, mas hoje absolutamente ultrapassadas, incómodas, negativas, desprestigiantes e nada recomendáveis num mercado especializado na produção, promoção e remoção de artigos que conhecem rápida e, não raras vezes, instantaneamente a inadequação e a desactualização, o envelhecimento e a obsolescência. Até parece que Guimarães Rosa adivinhava os contornos e implicações do nosso tempo, ao escrever esta passagem: "... o velho valeu enquanto foi novo..." 
Pessoas e instituições apenas estarão na crista da onda e da moda se exibirem um alto índice de proficiência na prontidão para a mudança. Para quê e porquê? A questão não tem grande sentido; a mudança vale por si mesma e, assim, fica a perder, é olhado de soslaio, com reserva e suspeita e coloca-se na contramão quem perguntar pelas justificações, pelas causas e pelos fins de um imperativo tão peremptório.

"Estar em movimento não é mais uma escolha: agora se tornou um requisito indispensável" - afirma Bauman. ${ }^{12}$

Mais importante do que estimular novos desejos e perspectivas é a ênfase de exacerbar a necessidade compulsiva de eliminar e extinguir tudo quanto foi adquirido antes, inclusive no instante imediatamente anterior. De levar os indivíduos ao desprendimento de ligações e apegos ao passado e às suas heranças e a quaisquer crenças, deixando-os livres, soltos e 'limpos' para vaguearem de uns momentos e eventos para os outros, cegos, desatentos ou despreocupados em relação às consequências e mais ainda no tocante ao destino a que isso conduz.

É nesta conformidade que Zygmunt Bauman regista, cataloga e descreve o aparecimento de um novo e intrigante modelo de homem: o homo eligens. ${ }^{13}$ Este não é aquele que tem competência e clarividência para discernir, optar e escolher, nem muito menos aquele que escolheu e assume convictamente as suas preferências, mas sim aquele que, a toda a hora, escolhe e muda de poiso, sítio e posição, de padrões e referências, numa procura incessantemente reiniciada e fracassada - e sem manual de instrução! - de montagem e solidificação da incerta, fluida e transitória identidade social, cultural e até sexual, abanado e levado pelas brisas do marketing e do mercado. Porque estar fixo, conservar afinidades e lealdades e ser identificado com estruturas que não contêm ou reproduzem a realidade do mundo é algo cada vez mais malvisto e é fonte de ridicularização e ansiedade. ${ }^{14}$

Esta corrida inglória e interminável, desenfreada e desaustinada, feita de desmedida aceleração e velocidade, mas sem sair do lugar, com incontáveis pontos de partida e sem meta de chegada, é incentivada pelo crédito bancário. Em vez da família, da escola e da universidade, são ele e os amplos e diversificados templos do mercado que garantem ter a resposta para o novo e obsessivo figurino do quebra-cabeças identitário em que a vida se deixa aprisionar e frustrar. Mas, por mais facilidades que o crédito aparente conceder, o desafio é desigual e enganoso: a maioria, pesem embora os seus denodados esforços para resistir, não ser sugada e passada pelos que andam e respiram nas suas costas e se movem pelos mesmos ímpetos, desesperos e motivos, não consegue competir, fracassa e cai no buraco fundo do excludente rebaixamento.

Como corolário deste ambiente de pesadelo, cresce em cada dia o número dos despromovidos e rebaixados, inexoravelmente condenados ao insucesso; só não vê quem não quer e se fecha à compreensão e aos dramas e angústias do seu semelhante. A liberdade e a segurança, ampla e intensamente cobiçadas e procuradas por serem indispensáveis a uma vida humanamente condigna e feliz, travam-se uma à outra; não alcançam um nível satisfatório de coordenação e coabitação, de equilíbrio e harmonia. Não é de estranhar que o vazio, as inseguranças, temores e depressões, o gigantesco estendal de biografias nada originais (tanto na forma como na substância), a insatisfação e a crise da identidade povoem esta hora. As tão cantadas promessas esboroam-se a olhos vistos e não vão além de um logro impingido aos incautos. O monte de destroços avoluma-se e dele sobe no ar um cheiro fétido: já chegamos à indiferença e ao desprezo pelo outro e pouco ou nada falta para cairmos no abismo da desumanidade. A sociedade do reconhecimento, da valorização e gratificação dos indivíduos é uma mistificação; acima de tudo ela instala-nos em modalidades de existir e funcionar indiferentes ao destino dos outros.

Afinal a ética, hoje prevalecente, tem a matriz de 'indolor'; mas, ao invés, a vida e a sociedade 'liquidas' do presente são uma fonte e um extenso mar de mortificação e dor, de iniquidade e injustiça, de abandono e frustração, de esquecimento e solidão. Tantas esperanças destruídas, tantas vidas desperdiçadas! O alerta de Platão (429-347 a.C.) - "temei a velhice, porque ela não vem só" - abrange agora a idade adulta, por outras e não menos desumanas razões.

A actual e funesta deriva da globalização desfigurou o mundo humano, desfocou-o e fê-lo imergir no negrume, tornou-o velho, cansado e irreconhecível: ele é cada vez menos atraente e fotogénico e cada vez mais hostil e indefensável. Assemelhamo-nos a 
figurantes num ensaio sobre o coração das trevas. Baixamos o olhar para não vermos os outros e o sofrimento reflectido nos seus olhos; e para que a aparente proximidade física não se choque com a sentida distância espiritual. Vamos ficando cínicos, assépticos, de sentimentos duros e enregelados, bem próximos da morte. O Outro não existe mais. ${ }^{15}$

\section{VOCABULÁRIO REFORMISTA, NOVAS APRENDIZAGENS E ÉTICA DE SERVIÇO}

No vocabulário 'reformista' do quotidiano entraram, estão muito na moda e usufruem de alta cotação novas palavras e expressões: 'criatividade', 'inovação', 'flexibilidade', 'adaptabilidade', 'modernização', 'aprendizagem para a mudança' etc. Estes termos camuflam as suas verdadeiras motivações e intenções e escondem a velhice e velhacaria da maldade. 'Convidam' as pessoas a deixar de ser o que são e a tornar-se naquilo que ainda não são, a aderir ao veloz e voraz e a rejeitar o estável e durável, a apreciar o frenesim e desdenhar da serenidade, a optar por ligações frouxas e ligeiras e por parcerias e compromissos que possam a toda a hora ser revogados e abandonados. Despromovem a incapacidade, a defeitos e a factores de prejuízo e insucesso os conhecimentos e saberes sólidos, a vinculação e fidelidade ao profundo e consistente, as atitudes e comportamentos louváveis, as habilidades e virtudes confiáveis. E promovem a competências, a mais valias e requisitos desta hora a disposição para destruir o que está feito e quem o fez, o apego à superficialidade e leviandade, ao postiço e movediço, às aparências e simulações, ao frágil, efémero e supérfluo, ao passageiro, fugaz e instantâneo, ao plástico e ao reciclado, a adesão à volatilidade e à inevitabilidade da desagregação e fragmentação da vida, da sociedade e das suas instituições. A dinâmica do transitório e ilusório subjuga o perene. Enfim, agora vale a propensão para a flutuação de posições e opiniões, para deitar fora visões do mundo e confiar na desordem e espontaneidade, para aceitar e encarar "as novidades como inovações, a precariedade como um valor, a instabilidade como um imperativo, o hibridismo como riqueza".

Avisadamente Zygmunt Bauman anota ainda: “'destruição criativa' é a forma como caminha a vida líquida, mas o que esse termo atenua e, silenciosa- mente, ignora é que aquilo que essa criação destrói são outros modos de vida e, portanto, de forma indirecta, os seres humanos que os praticam. A vida na sociedade líquido-moderna é uma versão perniciosa da dança das cadeiras, jogada para valer. O verdadeiro prémio nessa competição é a garantia (temporária) de ser excluído das fileiras dos destruídos e evitar ser jogado no lixo. E com a competição se tornando global a corrida agora se dá numa pista também global". 16

Ao cabo e ao resto, vivemos num tempo da pulsão da morte, em que esta, travestida de exclusão social, chega despida e nua antes da hora esperada, anunciando a sua presença irrevogável, apanhando as vítimas indefesas e acocoradas e proclamando o imperativo de nos acostumarmos e conformarmos à sua banalidade. Não vale a pena a imaginação humana procurar concorrentes e alternativas para ela. É deste jeito feio, medonho e grotesco que funciona hoje o mundo real. Sim, a exclusão dos outros tornou-se uma verdade banal, interiorizada e objectivamente praticada, mas que no entanto, talvez devido a alguma réstia de decoro ou vergonha ainda escondida, evitamos formular de maneira clara, inequívoca e explícita: as pessoas tentam excluir outras pessoas para evitarem serem excluídas. Mais, isto já está assimilado e é visto e entendido como ordinário e 'justificado'. Legitima-se num espírito ou mesmo pasme-se perante a aberração! - numa 'ética' de serviço; não é produto da intenção de agir errado e, portanto, não desperta qualquer noção de culpa, inquietação e remorso. A única e lamentável dor de alma que fica é a de não ter logrado maior nível de rentabilidade e eficácia na execução do trabalho, de não ter celebrado efusivamente e tirado a máxima gratificação dos sucessivos rituais da eliminação, de não ter sido mais reconhecida e louvada a sua exemplar proficiência no desempenho da tarefa, devidamente atribuída e confiada, de passar rasteiras e derrubar os outros. Eis como os direitos sociais são substituídos pelo dever individual de cada um cuidar de si e de levar vantagem sobre os demais! 17 Bertold Brecht (1898-1956) continua absolutamente actual: "Se os tubarões fossem homens (...) haveria escolas (...) A aula principal seria naturalmente a formação moral dos peixinhos. Eles seriam ensinados de que o ato mais grandioso e mais belo é o 
sacrifício alegre de um peixinho, e que todos eles deveriam acreditar nos tubarões, sobretudo quando esses dizem que velam pelo belo futuro dos peixinhos. Se encucaria nos peixinhos que esse futuro só estaria garantido se aprendessem a obediência (...) Se os tubarões fossem homens, haveria entre eles naturalmente também uma arte, haveria belos quadros, nos quais os dentes dos tubarões seriam pintados em vistosas cores e suas goelas seriam representadas como inocentes parques de recreio, nas quais se poderia brincar magnificamente (...) A música seria tão bela, tão bela, que os peixinhos (...) entrariam em massa para as goelas dos tubarões, sonhadores e possuídos pelos mais agradáveis pensamentos. Também haveria uma religião ali.

Se os tubarões fossem homens, eles ensinariam essa religião. E só na barriga dos tubarões é que começaria verdadeiramente a vida. Ademais, se os tubarões fossem homens, também acabaria a igualdade que hoje existe entre os peixinhos, alguns deles obteriam cargos e seriam postos acima dos outros. Os que fossem um pouquinho maiores poderiam inclusive comer os menores (...) Curto e grosso, só então haveria civilização no mar, se os tubarões fossem homens". ${ }^{18}$

\section{APELO À EDUCAÇÃO E FORMAÇÃ̃ - DÚVIDAS E DESAFIOS}

Contra isto levantam-se muitos lutadores solitários, teimosos, firmes, apegados e vinculados a ideais, princípios, valores e deveres que os intimam a pensar e agir de maneira ponderada. Porém assemelham-se a crianças perdidas e confusas, perante a dificuldade de se reunir e manter juntos numa sociedade individualizada, marcada pela retracção, pelo afrouxamento e pela liquefacção e destruição de laços e instituições sociais, logo com condições inóspitas para a acção cúmplice e solidária. Que fazer, neste mundo de representação e show, de ficção e simulacro, de actores, actrizes e protagonistas feitos de modo fácil e leviano, para juntar, tornar duráveis e sólidos os elos e os resistentes que se opõem à destruição da solidariedade? Só estimulando as pessoas a pensar e a envolver-se em modos de acção humanamente sensatos, louváveis e exaltantes, a empenhar-se na reconstrução do espaço público, da coesão e da ligação e interacção com os outros. ${ }^{19}$
A empresa é ingente e decerto teremos que a assumir ao longo deste século, para que no seu final a humanidade possa emergir mais segura e auto-confiante do que neste começo.

A ágora ou acrópole de que necessitamos, como de pão para a boca, é, porventura, uma universidade à altura da excelência no cumprimento da sua vocação, ousada, animada e apostada em erradicar o véu do obscurantismo, do pessimismo e paralisia da vontade com o optimismo do pensamento e a luminosidade da ética. É ela que, com análises exigentes, éticas e morais, lúcidas e cépticas, olhando e visionando o mundo de frente e sem o estreitamento de quaisquer lunetas ideológicas e receios de variada ordem, falando aberta, frontal e radicalmente de tudo, pode pôr a nu a tagarelice e a barganha dos arrebanhadores, suseranos e especuladores desta hora e a evidente corrosão do carácter que lhes está associada. É ela que deve tornar evidente e pública a imagem da feia realidade.

Ou seja, como sempre apela-se à educação e formação para encontrar uma resposta comum, para instilar nos estudantes motivações, convicções, reflexões e dúvidas que os levem a questionar a imagem e a noção de identidade que têm de si e do contexto social, a confrontar o perverso descaminho que percorremos, numa sociedade apagada e calada, domesticada, aninhada e submetida ao poderio esmagador do mercado e da publicidade enganosa que o sustenta, encobre e branqueia os seus desmandos e desvergonhas. Porém é pertinente e justo perguntar se aquelas, os seus agentes e instituições estarão à altura de tão descomunal tarefa; se terão ânimo e coragem e serão capazes de resistir e sobreviver e não serão, paradoxalmente, absorvidos ou esmagados pelos pavores e pressões que têm, por dever de missão e ofício, de enfrentar e pôr ao léu.

A desconfiança é legítima, porquanto a tipologia de implementação do dito e tão apregoado, exaltado e proclamado 'Processo de Bolonha' - notadamente em Portugal - parece ter sido fabricada de encomenda para impor o figurino de competências, aptidões e destrezas adequadas a esta era 'líquida' (de proposição, modelação e avaliação de simulacros de vidas despidas de atenções e dimensões humanas pelo exclusivo e redutor viés da gestão economicista), alicerçada em mistificações e manipulações, falsidades e inverdades, enganos e ludíbrios. ${ }^{20}$ 
Nos documentos a ele associados ou dele derivados a palavra 'educação' - tal como a bitola da 'qualidade', inicialmente tão empolada - evaporou-se gradativamente e foi condenada ao ostracismo. Em sua substituição sublinha-se e valoriza-se enfaticamente a aquisição de habilidades, aptidões e 'aprendizagens' direccionadas para os inconfessos objectivos, interesses e estratégias de abdicação, subjugação e dominação em nome da economia e do mercado neoliberal, não sendo atribuída grande ou cimeira importância à dimensão da formação do ser humano e de um senso de consciência e responsabilidade social. 21

O tão almejado "capacitamento dos cidadãos" sacrifica os fins da auto-afirmação, auto-aperfeiçoamento e auto-confiança às distorcidas e estultas antecipações e visões acerca das hipotéticas e improváveis necessidades de um mercado caótico e volátil. O mesmo é dizer que a educação não vale mais por si mesmo; o que conta não são disciplinas, matérias, abordagens e exigências contribuintes para a sabedoria e o desenvolvimento pessoal, mas sim aquilo que constitua uma ferramenta reconhecida pela ordem comercial, política e 'mercadológica' que tudo supervisiona. A preferência vai para a 'adaptação' - forma eufemística de dizer 'sujeição' - dos indivíduos ao ritmo acelerado da mudança, no lugar de os dotar de saberes e capacidades para entender e utilizar a mudança a favor da humanidade.

Para isto concorre igualmente a desvalorização das aulas, isto é, da forma de encontro frutífero das personalidades distintas dos professores e estudantes, da exposição e debate de temas e problemas relevantes, do despertar para ideias e projectos exaltantes, segundo a diferença, o desnível e a fragilidade das competências e perspectivas em presença. A sua diminuição e a substituição daquilo que constitui precisamente a causa e o sal do labor da formação por contactos, mensagens e consultas, através da internet, colocam o complementar no lugar do central, empobrecem a aprendizagem dos modos e normas do trato humano; levam a uma degradação do pensamento, da abstracção e conceptualização e atiram a apetência pela originalidade e pela leitura para as calendas gregas. Será muito raro o estudante que consegue ler um livro por ano e se liberta da mentalidade das 'sebentas'. ${ }^{22}$
Em todo o caso não há alternativa à educação e à esperança que nela mora. E por isso, assim o diz Henry A. Giroux, como conclusão de muitos anos de intensos estudos sobre as possibilidades da "pedagogia crítica": "Em oposição à acomodação, privatização e comercialização de tudo quanto é educacional, a educação superior precisa ser definida como um recurso vital para a vida cívica e democrática (...) O desafio é, portanto, para académicos, atores culturais, estudantes e sindicalistas se juntarem e se oporem à transformação da educação superior numa esfera comercial..."23 Para não ficarem de braços cruzados, quando não em atitude de cooperação, face à criação de um negócio florescente e, muitas vezes, desonesto de cursos de 'formação contínua' de inferior cotação, baixo nível, enganosos e até inúteis, porquanto nada oferecem ou adiantam de essencial para a melhoria da competência dos seus frequentadores, bem como para a contestação e transformação da ordem vigente. É exactamente por isso que tais cursos, elaborados e voltados, repete-se, não para qualificar os cidadãos, mas para os formatar, para explorar e tirar partido da pressão exercida sobre os potenciais consumidores e clientes, são facilmente aceites e vendidos e dificilmente - por vergonha ou incapacidade ou por ambas as coisas - desmascarados pelos aliciados e ludibriados. ${ }^{24}$

Em consonância e coerência com isto somos, mais uma vez, obrigados a denunciar as apelativas vantagens e os tão apregoados e inebriantes 'sucessos' garantidos à partida pelo 'Processo de Bolonha': certificados de destruição de utopias e ideais, produção em série de identidades sem solidez e consistência mental e com duradoira infantilidade, de "lumpen-proletários espirituais" amarrados ao presente e sem noção, visão e inquietação para o futuro. Eles poderão eventualmente vir a conhecer a riqueza material, mas dificilmente escaparão ao estado e à companhia permanente da pobreza, do fastio e cansaço espirituais. Digamo-lo sem quaisquer subterfúgios ou rodeios: a implementação economicista do Processo de Bolonha - repete-se, na versão consagrada em Portugal - é a maior traição à obrigação de formar quadros cultos, que se meçam à altura do seu tempo e sejam capazes de se sobrepor às suas vicissitudes e pobreza de espírito. A orfandade cultural e a insegurança pessoal são o seu traço mais marcante, não permitindo que a 
identidade, a adultidade e a liberdade saiam de um letárgico e persistente statu nascendi. ${ }^{25}$

Em jeito de reparo lateral, mas não irrelevante, fica aqui exarada uma pergunta que deveras nos perturba e deve ser colocada a muita gente: será viável um país pequeno, como Portugal, sem elites intelectuais, científicas e outras?

\section{CEPTICISMO NA UNIVERSIDADE, DEMOCRACIA E LIBERDADE}

O cepticismo sustenta-se na constatação de

Zygmunt Bauman, apoiada em Richard Rorty, de que "os gabinetes e corredores das universidades estão cheios de dois tipos de pessoas: alguns 'conformados aos critérios já bem definidos (...) e outros tentando 'expandir sua imaginação moral' e (...) ampliar o senso do que é possível e importante....".26 Ora não se pode olvidar que a 'lógica' deste tempo põe o segundo tipo de professores em nítida desvantagem e deixa "a academia, em geral, e os intelectuais humanistas, em particular, vulneráveis aos caçadores de heresias". E porquê? Porque "as mensagens (...) dos que promovem a conformidade contam com o apoio poderoso da opinião governante e das experiências cotidianas do senso comum..." Acresce que isso "também transforma os "intelectuais humanistas' em alvos fáceis para os defensores do fim da história, da escolha racional, das políticas existentes do tipo 'não há alternativa' e de outras fórmulas que tentam segurar e transmitir o atual e postulado ímpeto de uma dinâmica social aparentemente invencível. Isso provoca ataques de irrealismo, utopia, de pensamento positivo, fantasias e, acrescentando o insulto à injúria, numa odiosa reversão da verdade ética, irresponsabilidade". ${ }^{27}$ Para não falar noutras veladas insinuações e acusações explícitas, abjectas e mesquinhas, utilizadas para tentar beliscar e desacreditar os visados e para impressionar e provocar impacto e efeito junto dos portadores das mais diversas variantes do gene do preconceito!

Há tantos personagens e protagonistas da vida universitária - oh, se há! - que podiam enfiar muito bem esta carapuça, confeccionada na perfeição e à justa medida da sua cabeça! Todavia seria pedir-lhes demais; já atingiram um tal índice de conformismo, cinzentismo, entrega, submissão e mesmo de dogma- tismo e oportunismo que não lhes permite ver a imagem da sua postura e conduta reflectida neste espelho. Nem se dão conta de que, não obstante a medonha imensidão das forças adversas, uma sociedade democrática só na educação e formação é que tem meios para se avaliar, repensar e modificar. Só com elas se pode enfrentar o cenário de ignorância, causador de perdição e infelicidade. Sem elas a democracia definha e tende a não ir muito além da crescente passividade, da apatia e do virar de costas dos cidadãos. E também não se sustenta a liberdade, porque ela não é ganha para sempre, antes requer ser exposta, cultivada, adubada e regada diariamente.

Muito a propósito se anuncia a advertência de Henry A. Giroux e Susan Giroux: "A democracia está em perigo quando os indivíduos são incapazes de traduzir sua miséria privada em preocupações públicas e ação coletiva. Como as corporações multinacionais moldam cada vez mais os conteúdos da maior parte da grande mídia, privatizando o espaço público, o engajamento cívico parece cada vez mais impotente e os valores públicos se tornam invisíveis. Para muitas pessoas hoje em dia, a cidadania foi reduzida ao ato de comprar e vender mercadorias (incluindo candidatos), em vez de aumentar o escopo de suas liberdades e direitos a fim de ampliar as operações de uma democracia substancial". 28

Realmente, observou Pierre de Bourdieu (19302002), aquele que não compreende e domina o presente não consegue sonhar em controlar o futuro. Ademais - acrescenta Zygmunt Bauman - " a ignorância produz a paralisia da vontade", a "impotência do eleitorado", "a descrença generalizada na eficácia do dissenso", isto é, o capital político favorável, previdente, necessário e bem-vindo para se perpetuarem no poder os grupos dominantes. Para esses, "quando a voz da democracia corre o perigo de ser sufocada ou ter suas mãos atadas", vem mesmo a calhar "uma corda feita de ignorância e inação". É evidentemente contra isso que "precisamos da educação ao longo da vida para termos escolha. Mas precisamos dela ainda mais para preservar as condições que tornam essa escolha possível e a colocam ao nosso alcance". ${ }^{29}$ Enfim, só a educação e a formação geram a consciência de insatisfação com o patamar alcançado pela liberdade e a democracia. Ou seja, a democracia é pervertida e desviada do seu curso natural e a liber- 
dade estiola, quando a educação e formação se afastam da sua missão - a de formar homens de espírito livre e de consciência lúcida e indomável, a de fornecer aos indivíduos os instrumentos, o gosto e a obrigação da inquietação cívica e social, ética e moral - e, em vez disso, ajudam a meter as pessoas entre palas e varais e a empurrá-las para a demissão e rendição, uma a uma, dos fins, valores, bitolas e ideais humanistas, das pretensões e justificações da sociedade democrática. Novamente me assalta e acode à lembrança esta persistente e indeclinável dúvida: não é para esta perversão e desvirtuamento que o Processo de Bolonha dá uma 'preciosa' ajuda, se não for remendado em grande escala? 30

\section{RACIONALIDADE E BANALIDADE DO MAL CONTEMPORÂNEO}

O exame da situação manda concluir que o instrumentário racional e tecnológico, tão incensado nesta era, não se saiu melhor na luta contra o mal do que os paradigmas anteriores, combatidos pela mentalidade contemporânea, ávida de os arrasar e sepultar. O tormento do problema da identidade das pessoas está por resolver. Elas continuam a sofrer a pena do exílio e do desterro da cidadania como na antiguidade e na idade média; esta punição máxima adentrou a modernidade e afirma-se particularmente, de boa saúde e robusto vigor, na contemporaneidade.

Hannah Arendt fala do estado de choque, desnorte e desespero que se seguiu à primeira revelação dos horrores de Auschwitz e de outros campos de concentração. Ao desconforto inicial seguiu-se algo que não pode deixar de provocar uma amarga estranheza. Muitos não viram que os agentes do massacre fossem criminosos, uma vez que os sistemas jurídicos modernos assentam no pressuposto de que a existência de crime implica a intenção de agir maldosamente. E assim a morte de milhões de pessoas foi apenas o efeito colateral do facto de funcionários, técnicos e militares serem obedientes e eficazes, de cumprirem leal e cabalmente as ordens recebidas dos seus superiores.

A obediência e a execução 'perfeitas' do trabalho distribuído a cada um não poderiam ser postas em causa. Errado e descabido seria desobedecer a tais ordens. Portanto não se aplicaria a acusação de desumanidade e imoralidade ao caso de algumas pessoas cumprirem zelosamente as tarefas, obrigações e 'deveres' inerentes ao seu ofício e profissão, ao espírito e ética do serviço e de, em decorrência desse desempenho, terem outras pessoas sofrido vexames, torturas, suplícios e uma morte horrível. 31

O mal contemporâneo tornou-se, pois, uma coisa normal, banal e superficial; inspira-se no modelo de actuação perfilhado pelos súbditos de Eichmann. Um bom burocrata, para merecer o pão que come, deve escolher e esticar até ao limite os meios mais eficazes e adequados aos fins que lhe ordenaram atingir. Mais, não deve afastar-se da estrita, fria e técnica racionalidade e perder-se em indagações abrangentes e profundas; ao invés, deve testemunhar lealdade e solidariedade a todos os superiores e parceiros comprometidos com a missão.

Desta sorte o distintivo mais descarado, repelente e hediondo do mal hodierno, burocraticamente concebido e planificado, sancionado e organizado, administrado e realizado, não são tanto a sua banalização, perversidade e sordidez; é sobretudo a ignóbil 'racionalidade' que estrutura a cadeia hierárquica e nela deposita toda a responsabilidade, aliviando cada um das inquietações da consciência e das intimações da ética individual. ${ }^{32}$

Não é também isto que está a acontecer no ímpeto 'reformista' em curso na universidade e noutras instituições? A pergunta é formulada a partir da convicção da resposta, infelizmente afirmativa e dolorosa. Como no caso - lembrado por Hegel (1770-1831) a propósito da função da filosofia - da Coruja de Minerva, cujas asas se abrem e levantam voo à noite, isto é, quando o dia se foi e a escuridão invade a mente e o coração das pessoas, também no ímpeto destrutivo-reformista em curso acontece o mesmo, assim sopesado por Zygmunt Bauman: "Só se avalia plenamente o valor de alguma coisa quando esta some de vista - desaparece ou é delapidada". ${ }^{33}$

\section{REGRESSO AO OBSCURANTISMO}

Os factos não mentem; o seu apuramento e a sua extensa e repugnante lista provam que, após séculos de Iluminismo e Humanismo, de tantos idealistas, sonhadores e optimistas, estamos de volta ao ponto de partida. Auschwitz, Hiroxima e os vários Gulags representam o regresso à estupefacção, à incredulidade e ao desamparo do tsunami de Lisboa $^{34}$ e das 
catástrofes e tragédias das centúrias anteriores, a cenários de pânico e de horrores inimagináveis e imprevisíveis.

Apesar de termos e alardearmos mais conhecimentos do que os nossos ancestrais no começo da longa, árdua e sinuosa caminhada da humanidade, continuamos a ser apanhados e contraditos pela desolação, decepção e pessimismo de que não conseguimos separar-nos dos males, sejam eles materiais ou morais. Mais ainda, aprendemos a amarga e triste lição de que os males engendrados e produzidos pelos humanos são tanto ou mais horripilantes do que os resultantes das catástrofes naturais. E os de agora não têm menor grau de barbárie e brutalidade do que os cometidos pelos predecessores, nem são apenas obra de monstros, mas de seres comuns e bem parecidos, com cara simpática, boas palavras e maneiras polidas, próximos de nós e ocupantes do mesmo espaço; em caso contrário, até poderiam ser imaginados, mas não teriam tanta hipótese de ser consumados. Os males de agora são dissimulados e 'inteligentes' e uma obra da artimanha; contêm os ingredientes mais refinados e requintados de uma malvadez esperta e ardilosamente oculta. 35

O pior é que os escrúpulos morais, as dores de consciência, os impulsos à compaixão humana, a inclinação e a pulsão altruístas, o rebuço em infligir sofrimento e aflição aos outros, estes símbolos e padrões de nobreza, elevação e lhaneza de carácter e do nosso teor de decência e humanidade estão enfraquecidos, entregues ao desprezo e mesmo decapitados. Como assinala Hannah Arendt, a sociedade respeitável e moral como um todo, de uma forma ou de outra, sucumbiu a Hitler. E do mesmo modo desapareceram o mandamento religioso - "Não matarás!" - e as máximas éticas que guiam virtualmente a consciência e balizam realmente o comportamento humano. ${ }^{36}$

Este obscurantismo apoderou-se de nós e está de tal modo entranhado que não nos damos conta de que os execráveis chefes e ditadores renascem com novas e envernizadas versões e feições, à sombra da bandeira do despudor de propostas e juramentos de 'reformas' que prometem um mundo melhor e o imediato e tão ansiado encontro com a felicidade. Ora isto permite concluir que a tortuosa racionalização tecnocrática e burocrática logrou conseguir os seus intentos: estamos treinados, com a desejada efi- ciência, a fechar os olhos e a tapar os ouvidos àquilo que possa perturbar, desassossegar e incriminar a nossa tranquilidade e letárgica consciência. E enquanto isso durar, enquanto nos fecharmos ao imperativo ético de recordar e perguntar, de pensar e argumentar, de olhar e avaliar, de reflectir e reagir, a dourada incubadora de medos e terrores, de desconfianças de tudo e todos vai crescendo e alargando o seu raio de acção. 37

Nós somos, sem a mínima sombra de dúvida, estimáveis e confiáveis. Agora os outros, anónimos, estranhos e sem rosto familiar, com os quais nos cruzamos todos os dias, não o são! Esses são, sim, a fonte de ameaça vaga e difusa que se declara como um perigo à menor faísca do medo.

Nesta conformidade as cidades, que outrora foram concebidas como uma acrópole da convivência, da inter-ajuda e mútua protecção, ao se perceberem como campos férteis e propícios a inseguranças e a violência, transformaram-se em conglomerados de construções que configuram uma arquitectura e uma vida de 'bunker'. Estão cheias de condomínios que retalham e segmentam o território urbano com graves e inaceitáveis intenções e consequências políticas e cívicas, dado que neles nascem e crescem gerações inteiras enclausuradas do contacto e confronto com os outros, com a pobreza e as dificuldades económicas e sociais, com opiniões, condições, visões e estilos de vida diversos, fechadas à prática da tolerância à diferença e à compreensão e partilha da cidadania. Como se fossem uma Caixa de Pandora de sentido inverso ao original: desta feita para guardar no seu interior os indivíduos e para os proteger contra os ventos funestos que sopram no exterior. É este marco orientador que anima igualmente as leis de imigração da União Europeia e de outros países. Cuidando que levantar fortalezas e barricadas de isolamento e manter à distância as supostas ameaças é a melhor forma de proceder, de viver, de preservar e difundir os princípios e valores que perfazem o nosso ideário e crença. Em vez de elaborar e implementar políticas tendentes a uma redução drástica da miséria, tomam-se medidas que alimentam a xenofobia e o racismo. 38

Eis um descaso e uma imprudência que havemos de pagar bem caro! Logo não temos direito à tranquilidade e ao descanso, ao sacudir de ombros e à aco- 
modação, à indiferença e inacção, à demissão e aposentação; estamos intimados a escrever na Universidade e fora dela, em cada dia, com a tinta e a palavra das nossas posições, afirmações e comportamentos, o livro da repulsa e indignação, da intrepidez e denúncia, do desassossego e desassombro - e da assunção e desobrigação dos mandamentos e responsabilidades que nos tocaram em sorte nesta única, valiosa e insubstituível existência.

Nesta hora de desclassificação e relativismo culturais e axiológicos - de vale tudo, de progressão do grotesco, de aniquilação da estesia, de elitismo invertido (de adulação da mediocridade e do nivelamento por baixo, de celebração do bacoco e do boçal, do vulgar e do reles, do pacóvio e do popularucho), de sedução do evanescente, de estabelecimento de uma ortodoxia pedagógica que faz tábua rasa da dificuldade e endeusa o relaxamento, a preguiça e o abaixamento das exigências, de florescimento da 'cultura' da indolência e passividade, de prevalência da ética indolor, da acrasia e desídia, de afundamento no delíquio e no pasmo, de adesão à facilitação e ao esquecimento dos deveres - é de brio, de vontade e de convicção moral que mais precisamos na educação, na formação, na Universidade e na vida. Para formularmos perguntas e questões fulcrais, levantarmos dúvidas e reservas, buscarmos dissipar um pouco a névoa que nos cerca, estarmos à altura das nossas perplexidades, não trairmos e sermos dignos do estatuto universitário.

O problema da condição e civilização contemporâneas é que elas pararam de se questionar e de ser questionadas. É perante este quadro que Bauman nos coloca e recrimina: "Não formular certas questões é extremamente perigoso, mais do que deixar de responder às questões que já figuram na agenda oficial; ao passo que responder o tipo errado de questões com frequência ajuda a desviar os olhos das questões realmente importantes. O preço do silêncio é pago na dura moeda corrente do sofrimento humano. Fazer as perguntas certas constitui, afinal, toda a diferença entre sina e destino, entre andar à deriva e viajar. Questionar as premissas supostamente inquestionáveis do nosso modo de vida é provavelmente o serviço mais urgente que devemos prestar aos nossos companheiros humanos e a nós mesmos". 39
É com a assunção deste imperativo e arrojo que havemos de ir além de Bolonha e das reformas, propagandas e publicidades que nos impingem e confundem, perscrutar e desvendar os seus intuitos e consequências, enfrentar e transpor os velados artifícios e ameaças da censura e da limitação, do constrangimento e da intimidação que nos fendem o ânimo, vendam os olhos e tolhem os passos. 40

\section{CONCLUSÃO: CONFISSÃO E ESPERANÇA}

Em suma, esta nossa época reflecte a crise de desajustamento entre o passado e o presente; mina os vínculos humanos e a confiança neles depositada. Diluem-se as normas e formas do trato e relacionamento e as obrigações mútuas que os humanos devem ter entre si. Vive-se em estado de alerta e inquietação permanentes, despertadas por sinais que não cessam de nos avisar. A vida e a cidade já não nos pertencem; temos melancolia e nostalgia do que foram, tornaram-se não-lugares, um abismo onde o humano se encolhe e anula e que a saudade não consegue transpor, sendo esta a pesada herança que transportamos e passamos de mão em mão.

Ao fim e ao cabo, resta-nos recuperar a memória de nómadas remotos e deitar mão às novas tecnologias, aos telemóveis ou telefones celulares e ao e-mail, para procurarmos na errância e na distância as redes e apoios de amigos cúmplices, confidentes e seguros que nos faltam na proximidade e para tentarmos fugir aos problemas e dramas, às incompreensões, instabilidades e depressões que o dia-a-dia nos coloca e tanto nos angustiam. Todavia isto traduz, paradoxalmente, o declínio do espaço verdadeiramente público e naufraga na decepção; não chega para furarmos o cerco que nos impõe e torna irrespirável a opressora e entediante condição de nómadas 'sitiados'. Ligados ao telefone ou à internet, desligamo-nos da vida e esta torna-se fugidia, procuramos em vão refúgio e amparo, identidade e compensação nas suas margens e perdemos a capacidade de um relacionamento intenso e espontâneo com pessoas reais. ${ }^{41}$

Dito de um modo cru, parecemos peregrinos, andarilhos e náufragos perdidos, exauridos e entregues aos humores do acaso num mar de cerração, sem vislumbrar a luz e o rumo de um farol que nos guie ao conforto da terra firme. A neblina deste "mundo líquido-moderno” é - diz Zygmunt Bauman - "ines- 
crutável, opaca, impermeável (...) o esconderijo favorito do mal. Feita dos vapores do medo, a neblina exala o mal". 42

Só nos daremos conta destes tempos vis, cavernosos e sombrios e daquilo que se acoita no seu bojo, se vivermos o bastante para perceber, superar e ultrapassar o actual e envergonhado estado de sonolência, resignação e capitulação. Se abrirmos janelas amplas e festivas para as benquistas perspectivas e as refrescantes e inebriantes lufadas de bonança, susceptíveis de, no dizer de Zygmunt Bauman, “tornar o mundo humano um pouco mais hospitaleiro para a humanidade". 43

Diremos então, em tom e atitude de contrição e arrependimento e de proclamação e juramento, o credo de Jorge Luís Borges (1899-1986): “O dever de todas as coisas é ser uma felicidade”. É crime hediondo excluir as pessoas dessa meta e possibilidade. E reconheceremos também como Simone Weil (1909-1943): "o bem é aquilo que dá maior realidade aos seres e às coisas; o mal é aquilo que disso os priva".

Até lá, se preferirmos o adormecimento à vigília e o silêncio à denúncia, andaremos à deriva, agarrados ao leme da incerteza e indecisão, da cobardia e do pavor, deambulando por entre receios, fantasmas e assombramentos e procurando afincadamente resistir aos ventos da má sorte e desgraça, consertar as velas esfarrapadas e não naufragar e submergir nos baixios do medo de ser deixado para trás. Sem ousadia e sem dignidade, sem honra e sem glória.

\section{NOTAS}

${ }^{1}$ Estas reflexões apoiam-se em várias obras de Zygmunt Bauman, nomeadamente: GLOBALIZAÇÃO: As consequências humanas, Jorge Zahar Editor, Rio de Janeiro, 1999; IDENTIDA$D E$ - Entrevista a Benedetto Vecchi, Jorge Zahar Editor, Rio de Janeiro, 2005; VIDAS DESPERDIÇADAS, Jorge Zahar Editor, Rio de Janeiro, 2005; VIDA LÍQUIDA, Jorge Zahar Editor, Rio de Janeiro, 2007; MEDO LÍQUIDO, Jorge Zahar Editor, Rio de Janeiro, 2008.

${ }^{2}$ These reflections rely on several works of Zygmund Bauman, namely: GLOBALIZAÇÃO: As consequências humanas, Jorge Zahar Editor, Rio de Janeiro, 1999; IDENTIDADE - Entrevista a Benedetto Vecchi, Jorge Zahar Editor, Rio de Janeiro, 2005; VIDAS DESPERDIÇADAS, Jorge Zahar Editor, Rio de Janeiro, 2005; VIDA LÍQUIDA, Jorge Zahar Editor, Rio de Janeiro, 2007; MEDO LÍQUIDO, Jorge Zahar Editor, Rio de Janeiro, 2008.

${ }^{3}$ A disfunção mais potencialmente explosiva do mercado neoliberal actual não é a exploração, típica da economia capitalista, mas sim a exclusão. É esta que origina os casos mais evidentes da polarização social, do aprofundamento da desigualdade e do aumento da miséria e humilhação. (Zygmunt Bauman, IDENTIDADE - Entrevista a Benedetto Vecchi, Jorge Zahar Editor, Rio de Janeiro, 2005, p. 47).

${ }^{4}$ Há um ditado das gentes trasmontanas que se aplica bem a esta conjuntura; reza o seguinte: "O céu é de quem o ganha; e o mundo de quem mais arrebanha." Os arrebanhadores estão em alta.

${ }^{5}$ Mário Soares, ex-Presidente da República, acentua que estamos perante a mais grave de todas as crises: "crise moral, crise de valores ou melhor da falta deles, a negação da ética, (...), crise civilizacional, (...) a impunidade da corrupção, (...) numa sociedade individualista, egoísta e consumista, por excelência, em que conta, acima de tudo, o dinheiro - como supremo valor." (Diário de Notícias, Lisboa, 21.10.2008)

${ }^{6} \mathrm{E}$, porque a voz dorida desses homens e mulheres não é ouvida, entregam-se à mudez, à apatia, à descrença e ao desespero, não surpreendendo que muitos vejam na "promessa fundamentalista de 'renascer' num novo lar cordial e seguro (...) uma tentação à qual é difícil de resistir". Na ausência de uma alternativa de certo preferida, a "terapia fundamentalista (...) parece sedutoramente simples". (Ibidem, p. 53-54).

${ }^{7}$ Há programas (p. ex., The Weakest Link) em que nem todos são eliminados; salva-se um, o vencedor, todos os outros são descartáveis. É como o lema "vence ou morre" e as dicotomias "vitória-derrota" e "sucesso-insucesso" que conhecemos e criticamos no desporto, mas vigoram no contexto social. Só há lugar para o vencedor; os restantes são todos metidos no lote dos derrotados e excluídos. (Ver Zygmunt Bauman, $M E D O$ LÍQUIDO, Jorge Zahar Editor, Rio de Janeiro, 2008, p. 42-43). ${ }^{8}$ Ibidem, p. 36-44.

${ }^{9}$ Zygmunt Bauman, VIDA LÍQUIDA, Jorge Zahar Editor, Rio de Janeiro, 2007, p. 16-18.

${ }^{10} \mathrm{O}$ corpo (consumista, consumidor e consumido) também é distintivo, objecto e alvo de interesse da sociedade de consumo. Como tal é palco da incentivada e incessante reformulação da identidade, alimentada pela exploração do capital de inseguranças e medos constantemente agitados. Consequentemente a insana busca ou jihad pela imagem, forma, condição e aptidão corporais ideais - nunca de todo atingidas e atingíveis - desperta enorme fervor e encaixa, de maneira perfeita, na lógica do mercado. Urge separar as águas: uma coisa é a saúde, outra é a doença da obsessão. O corpo tornou-se auto-télico, a imagem 
um deus, as rugas uma contravenção, a gordura um pecado mortal, a celulite um descaso, a dieta uma religião e a exercitação (sobretudo a musculação) um ritual de penitência e expiação. O bom senso parece ser perdido à medida que cresce a obstinação dos adultos em fabricar a eterna juventude e em livrar-se ou evitar o aparecimento dos estigmatizados sinais de velhice. Ora isto não é natural. Tudo convida a gastar tempo, esforço e recursos com o artificial; nada sobra para investir na cultura e sabedoria da vida.

De resto o cultivo hodierno do corpo segue e desvirtua a linha aberta pela ciência da modernidade. É expressão do aprofundamento da destruição do sagrado e do eterno. A preocupação com o agora e a absolutização da máxima carpe diem não deixa lugar para o transcendente; retalha os grandes problemas e conduz à concentração em assuntos de menor escopo, que podemos abordar, tentar controlar e resolver e não se estendem aparentemente para além da nossa existência. Ademais, na voracidade da mudança e no golpe mortal desferido no valor da durabilidade, a longevidade corpórea da nossa existência surge como a única identidade com expectativa da vida crescente. É, pois, mais rentável investir na vida corpórea individual do que em "causas eternas". Isto é, tudo o que não seja investir no prolongamento da vida individual "parece um mau investimento". Caiu em desuso o projecto de construção da ponte entre a brevidade da nossa vida e a eternidade do universo, árdua e laboriosamente empreendido durante milénios em todos os contextos culturais. Deste jeito é também abandonada a reflexão filosófica acerca a ideia da verdadeira felicidade, resultante da associação dos nossos actos e práticas a 'coisas' maiores e mais duradoiras do que a vida corpórea - e que esta não contém. (Ver Zygmunt Bauman, IDENTIDADE - Entrevista a Benedetto Vecchi, Jorge Zahar Editor, Rio de Janeiro, 2005, p. 80-82).

${ }^{11}$ Mutatis mutandis, tem inteiro valimento na conjuntura actual a máxima do poeta latino Ovídeo (43 a.C.-18 d.C.): "Enquanto fores feliz contarás muitos amigos; quando o tempo se tornar nublado estarás só".

${ }^{12}$ Zygmunt Bauman, IDENTIDADE - Entrevista a Benedetto Vecchi, Jorge Zahar Editor, Rio de Janeiro, 2005.

${ }^{13}$ Zygmunt Bauman, VIDA LÍQUIDA, Jorge Zahar Editor, Rio de Janeiro, 2007, p. 48. Falta criar uma designação em latim para o modelo de homem que, além de passar de produtor a consumidor, parece ter conveniência, necessidade e prazer em prescindir da construção da identidade, em se despir de qualidades e desprender de vínculos e compromissos, tradicionalmente aceites e valorizados.

${ }^{14}$ Zygmunt Bauman define enfaticamente e a preceito: "A liberdade das pessoas em busca de identidade é parecida com a de um ciclista; a penalidade por parar de pedalar é cair, e deve-se continuar pedalando para manter a postura ereta. A necessidade de continuar na labuta é um destino sem escolha, já que a alternativa é apavorante demais para ser considerada".

(Zygmunt Bauman, VIDA LÍQUIDA, Jorge Zahar Editor, Rio de Janeiro, 2007, p. 47).

${ }_{15}$ Porventura este descalabro e queda no abismo da inumanidade não são estranhos à extraordinária, eufórica e fervorosa mobilização em torno do fenómeno Barack Obama, ao enorme grau de expectativas e confiança nele depositadas. Poderá ele corresponder e ser factor das tão almejadas alteração, correcção e transformação deste curso do mundo do nosso descontentamento? Nada mente a uma esperança, se o não vir da sua concretização e da certeza, que nela mora, nos dói muito. Restanos redobrar de vigilância e acção, aderir à crença e partilhá-la persuasivamente, para tentarmos sair do horrendo buraco negro criado pelo desregulado e necrótico mercado neoliberal e financeiro.

${ }^{16}$ Zygmunt Bauman: VIDA LÍQUIDA, Jorge Zahar Editor, Rio de Janeiro, 2007, p. 10.

${ }^{17}$ Apetece evocar Rui Barbosa (1849-1923), eminente tribuno brasileiro: "De tanto ver triunfar as nulidades, de tanto ver crescer as injustiças, de tanto ver agigantarem-se os poderes nas mãos dos maus, o homem chega a desanimar da virtude, a rir-se da honra, a ter vergonha de ser honesto".

${ }^{18}$ As transcrições são excertos do texto Se os tubarões fossem homens, disponível na internet.

19 O espartilho ideológico da conjuntura é tão eficaz e sub-reptício que até mesmo académicos movidos pelos melhores intuitos humanistas elaboram programas de actividades corporais referenciadas à saúde, destinados a adultos e idosos, visando que estes os cumpram em casa e não 'necessitem' de frequentar o espaço público. Sem se darem conta, caem na esparrela e ajudam a enfunar as velas da destruição das instituições sociais com vento neoliberal.

${ }^{20} \mathrm{O}$ Processo de Bolonha pode ser visto a partir de várias posições. Uma coisa é vê-lo em abstracto: merecem concordância geral os princípios e fins nele genericamente enunciados e confessados. Outra coisa é apreciar as motivações subliminares e inconfessáveis e a concretização do processo caso a caso, em função da pertença do analista a uma determinada área; esta, com a respectiva especificidade de saberes e convicções e de afinidades com o modelo de desenvolvimento económico em vigor, condiciona obviamente a visão, sempre parcial do avaliador. 'Bolonha', na versão portuguesa e com o pacote de medidas, leis e 'reformas' que o governo adicionou ao processo, é a cereja no topo do bolo servido em três dulcíssimas e complementares variantes: Bulonha, uma bula em que tudo é determinado, prescrito e imposto de fora, hierarquizando e distinguindo as áreas académicas com diferentes soluções no tocante à extensão da formação obrigatória, desconsiderando e asfixiando assim algumas (p. ex., as sociais e humanas) com um apertado garrote orçamental; Borlonha, uma borla que isenta os estudantes de um esforço e empenhamento por aí além e o Estado do devido investimento financeiro; Burlonha, uma burla em todos os capítulos, ao serviço de uma agenda oculta no plano económico e de uma pobreza cultural e espiritual, conveniente aos suseranos desta hora. Admito que outra seja a leitura de alguém ligado às bio-tecnologias; contudo espera-se que os especialistas destas áreas aceitem também a parcialidade da sua visão e não repitam festivamente as frases do pensamento único ditadas pelo mercado neoliberal, sem regulação e controle de espécie alguma, sem transparência e um pingo de ética e responsabilidade humana e social.

${ }^{21}$ Nesses documentos a palavra 'educação' é substituída por 'aprendizagens". Porque será? Os motivos são óbvios: a 'educação' é uma atribuição do Estado, compete a este garanti-la; as 'aprendizagens' inscrevem-se na lista de obrigações e responsabilidades dos indivíduos, são eles que as devem adquirir ao longo da vida, se quiserem ter sucesso e não ser atirados pela borda fora. Está assim aberto o caminho para um novo e lucrativo comércio.

${ }^{22}$ Mas então o Processo de Bolonha não pode impulsionar perspectivas e medidas superiores? Eis a resposta de Manuel Ferreira Patrício: "Parece-me que, até este momento, as instituições estão mais preocupadas com a sua sobrevivência do que com o que devem ser os seus objectivos lidimamente académi- 
cos. Por isso as perspectivas e medidas indiciam mais o propósito de atrair clientes do que o de promover formas e métodos de saber e saber-fazer dignos do qualificativo de superiores". (In itinerários - revista de educação, $2^{\mathrm{a}}$. Série, $\mathrm{n}^{\circ}$. 6, Junho de 2008, p. 215, Instituto Superior de Ciências Educativas, Odivelas).

${ }^{23}$ Henry A. Giroux e Susan Searls Giroux, Take Back Higher Education (Palgrave, 2004). (Ver Zygmunt Bauman, VIDA LÍQUIDA, Jorge Zahar Editor, Rio de Janeiro, 2007, p. 21). ${ }^{24}$ Este panorama leva Wojciechowski a afirmar que os únicos cursos, permitidos a instituições de duvidosa credibilidade, deveriam ser os de odontologia, sob a condição de que os respectivos professores venham a tornar-se pacientes nos consultórios e clínicas a abrir futuramente pelos seus ex-alunos. (In: Zygmunt Bauman, VIDA LÍQUIDA, Jorge Zahar Editor, Rio de Janeiro, 2007, p. 157).

${ }^{25}$ Há, porventura, algum exagero nestas formulações.

Carreguei propositadamente nas tintas, tendo plena consciência de que exagerar é, muitas vezes, a única maneira de alertar. Todavia há razões e justificações de sobra para a denúncia e o alerta.

${ }^{26}$ Richard Rorty, "The humanistic intellectuals: eleven theses", in Philosophy and Social Hope, Penguin, 1999. (Ver Zygmunt Bauman, VIDA LÍQUIDA, Jorge Zahar Editor, Rio de Janeiro, 2007, p. 22).

${ }^{27} \mathrm{Ibidem}$, p. 22.

${ }^{28}$ Ibidem, p. 164.

${ }^{29}$ Ibidem, p. 166-167.

${ }^{30}$ Felizmente, pouco a pouco, surgem sinais de denúncia e revolta e vão-se erguendo em alto e bom som, no campo da política, vozes reprovadoras da desfiguração e modelação economicistas que têm sido impostas às Universidades. Por exemplo, Manuel Alegre, deputado do partido do governo, é particularmente incisivo e duro: "Universidades não são unidades de produção (...) não servem para formar quadros para satisfazer as necessidades das empresas ou a economia de mercado". (Ver Diário de Notícias, 12.11.2008)

${ }^{31}$ Hannah Arendt, Eichmann in Jerusalem, Viking, 1963. (Ver Zygmunt Bauman, MEDO LÍQUIDO, Jorge Zahar Editor, Rio de Janeiro, 2008, p. 81-84).

32 A ética do cuidado de si e dos outros, postulada pelo filósofo Martim Heidegger (1889-1976), incita cada um em particular e o Estado em geral a cumprir a sua parte, no tocante à melhoria da vida pessoal e social. Hoje o Estado neoliberal liberta-se desse preceito. Paradoxalmente, o indivíduo é cada vez mais responsabilizado pelo seu destino, mas a responsabilidade e a culpa individuais pelo mal-estar social e os agravos sofridos pelos outros são ofuscadas e depositadas na conta da lógica do sistema.

${ }^{33}$ Zygmunt Bauman, IDENTIDADE - Entrevista a Benedetto Vecchi, Jorge Zahar Editor, Rio de Janeiro, 2005, p. 52.

${ }^{34} \mathrm{O}$ dito terramoto - na verdade um cataclismo idêntico ao que hoje se designa por tsunami - que devastou Lisboa, em 1755, constituiu um abalo no pensamento europeu e ficou indelevelmente ligado à elaboração de traves mestras e ideais do Iluminismo e Humanismo. A filosofia moderna seguiu, no estabelecimento da sua função, o padrão inerente à actuação e preocupação do Marquês de Pombal, primeiro-ministro português na época: erradicar os males produzidos por mãos humanas. (Ver Zygmunt Bauman, MEDO LÍQUIDO, Jorge Zahar Editor, Rio de Janeiro, 2008, p. 80).

35 Obviamente não é espectável que os políticos e governos sejam infalíveis; mas não é demais exigir e esperar que sirvam o bem e o interesse públicos, sejam honestos, vinculados à verdade e propensos a assumir responsabilidades.

${ }^{36}$ Zygmunt Bauman, MEDO LÍQUIDO, Jorge Zahar Editor, Rio de Janeiro, 2008, p. 84-86.

${ }^{37}$ Mais uma vez é pertinente lembrar Bertold Brecht e o poema, de sua autoria, Escuta Zé Ninguém: "Primeiro vieram buscar os comunistas./Não disse nada, pois não era comunista;/depois, vieram buscar os judeus. Nada disse, pois não era judeu;/.../Agora, vieram buscar-me a mim,/e quando isso aconteceu, não havia mais ninguém para protestar."

${ }^{38}$ Zygmunt Bauman, VIDA LÍQUIDA, Jorge Zahar Editor, Rio de Janeiro, 2007, p. 91-105.

${ }^{39}$ Zygmunt Bauman, GLOBALIZAÇÃO: AS CONSEQUÊNCIAS HUMANAS, Jorge Zahar Editor, Rio de Janeiro, 1999, p. 11. ${ }^{40}$ Numa crónica intitulada $A$ maldição dos intelectuais, inserta no jornal Público de 12.11.2008, p. 40, Rui Tavares pergunta e responde: "Que deve um intelectual fazer? (...) Se quiser fazer vingar as suas ideias, terá de lutar por elas nos seus próprios termos. (...) Se acredita que as ideias são importantes como causa, deveria também acreditar que elas são importantes como resultado. Está no seu interesse criar um ambiente em que as ideias, mesmo as mais complexas, sejam acarinhadas".

${ }^{41}$ Segundo Charles Handy, as comunidades virtuais, além de tornarem mais difícil para a pessoa a questão da substância da identidade pessoal e de chegar a um acordo com o próprio eu, não podem ser um substituto válido de "sentar-se a uma mesa, olhar o rosto das pessoas e ter uma conversa real".

A isto acresce, segundo Andy Hargreaves, a extinção da introspecção. "Defrontadas com momentos de solidão em seus carros, na rua ou nos caixas de supermercados, mais e mais pessoas deixam de se entregar a seus pensamentos para, em vez disso, verificarem as mensagens deixadas no celular em busca de algum fiapo de evidência de que alguém, em algum lugar, possa desejá-las ou precisar delas". (Zygmunt Bauman, IDENTIDADE - Entrevista a Benedetto Vecchi, Jorge Zahar Editor, Rio de Janeiro, 2005, p. 31-32).

${ }^{42}$ Zygmunt Bauman, MEDO LÍQUIDO, Jorge Zahar Editor, Rio de Janeiro, 2008, p. 95.

${ }^{43}$ Zygmunt Bauman, VIDA LÍQUIDA, Jorge Zahar Editor, Rio de Janeiro, 2007, p. 23. 